\title{
Functional profile of human influenza virus-specific cytotoxic $T$ lymphocyte activity is influenced by interleukin-2 concentration and epitope specificity
}

\author{
A. C. M. Boon, G. de Mutsert, \\ R. A. M. Fouchier, \\ A. D. M. E. Osterhaus and \\ G. F. Rimmelzwaan \\ Department of Virology and WHO National \\ Influenza Center, Erasmus Medical Center, \\ Rotterdam, the Netherlands
}

Accepted for publication 7 June 2005

Correspondence: G. F. Rimmelzwaan, Erasmus

Medical Center, Institute of Virology, PO Box

1738, 3000 DR Rotterdam, the Netherlands.

E-mail: g.rimmelzwaan@erasmusmc.nl

\begin{abstract}
Summary
The ability of influenza A virus-specific cytotoxic T lymphocytes (CTL) to degranulate and produce cytokines upon antigenic restimulation was studied in four HLA-A ${ }^{\star} 0101$ and HLA-A ${ }^{\star} 0201$ positive subjects. Peripheral blood mononuclear cells of these subjects were stimulated with influenza A virus in the presence of high or low interleukin (IL)- 2 concentrations. $\mathrm{CD}^{+} \mathrm{T}$ cell populations specific for the HLA- $\mathrm{A}^{\star} 0101$ restricted epitope $\mathrm{NP}_{44-52}$ and the HLA-A ${ }^{\star} 0201$ restricted epitope $M 1_{58-66}$ were identified by positive staining with tetramers of peptide major histocompatibility complexes (MHC) (NP-Tm and M1-Tm, respectively). Within these populations, the proportion of cells mobilizing CD107a, or expressing interferon (IFN) $\boldsymbol{\gamma}$ and tumour necrosis factor-(TNF)- $\alpha$ upon short-term peptide restimulation was determined by flow cytometry. Independent of IL-2 concentrations, large subjectdependent differences in the mobilization of CD107a and expression of IFN- $\boldsymbol{\gamma}$ and TNF- $\alpha$ by both NP- and M1-specific T cells were observed. In two of the four subjects, the functional profile of $\mathrm{NP}-\mathrm{Tm}^{+}$and $\mathrm{M} 1-\mathrm{Tm}^{+}$cells differed considerably. Overall, no difference in the proportion of NP- $\mathrm{Tm}^{+}$or M1$\mathrm{Tm}^{+}$cells expressing CD107a was observed. The proportion of $\mathrm{M1}-\mathrm{Tm}^{+}$cells that produced IFN- $\gamma(P<0 \cdot 05)$ was larger than for NP- $\mathrm{Tm}^{+}$cells, independent of IL-2 concentration. When cultured under IL- $2_{\mathrm{hi}}$ concentrations higher TNF- $\alpha$ expression was also observed in M1-Tm ${ }^{+}$cells $(P<0 \cdot 05)$. The IL- 2 concentration during expansion of virus-specific cells had a profound effect on the functionality of both $\mathrm{M} 1-\mathrm{Tm}^{+}$and NP- $\mathrm{Tm}^{+}$cells.
\end{abstract}

Keywords: CD107a, cytokines, cytotoxic T lymphocytes, epitopes, influenza virus

\section{Introduction}

Cytotoxic T lymphocytes (CTL) play an important role in the control of virus infections, including those caused by influenza viruses $[1,2]$. Important effector cell functions include the killing of virus-infected cells through the excretion of perforin and granzyme molecules or induction of apoptosis through Fas/FasL signalling, and the production of cytokines such as interferon (IFN) $-\gamma$ and tumour necrosis factor (TNF)- $\alpha$ [3].

Recent research has identified differential expression of CD45R isoforms, CCR7, CD62L, CD27, CXCR4 and CD28 on functionally different $\mathrm{CD} 8^{+} \mathrm{T}$ cell populations [4-12], which have been associated with consecutive stages of human $\mathrm{CD}^{+} \mathrm{T}$ cell development during and after acute viral infections. Upon infection naive, effector and memory cells, each with their own characteristics regarding cytokine production, proliferation and effector function, were discriminated. Peptide-HLA class I tetramers (Tm) have also been used to study CTL populations specific for distinct viral epitopes from various viruses (human immunodeficiency virus (HIV), cytomegalovirus (CMV), Epstein-Barr virus (EBV), hepatitis $C$ virus and influenza $A$ virus [13-17], demonstrating differences in perforin and granzyme expression, lytic capacity, cytokine production and cell surface molecule expression between the different epitope-specific CTL populations. In mice, CTL specific for the F- or G-protein of respiratory syncitial virus (RSV) produced less IFN- $\gamma$ than CTL specific for an epitope of influenza A virus [18]. It is unknown, however, whether these functional and 
phenotypical differences in CTL are the result of different virus aetiologies or epitope/HLA-specificities or both. Limited data are available on functional heterogeneity in CTL populations specific for various epitopes from a single virus [16,19-22]. Differences in cell surface marker expression and/or cytokine production in human CTL specific for different EBV epitopes and mouse CTL specific for two different influenza virus epitopes have been reported [20,22]. We also demonstrated differences in cytokine expression profiles for influenza virus-specific CTL restricted by different HLA class I molecules. CTL specific for HLA-A1 restricted epitopes produced more TNF- $\alpha$ than IFN- $\gamma$, while HLA-B8, -B35 and -A2 restricted epitope-specific CTL produced mainly IFN- $\gamma$ and to a lesser extent TNF- $\alpha$ [23].

The roles of microenvironment, $\mathrm{T}$ cell receptor (TCR) avidity, peptide concentration, and co-receptor dependence in defining CTL effector functions are still largely unclear. Some studies have demonstrated a positive relationship between TCR avidity and functional profiles of epitopespecific CTL [24], while other studies dispute this relationship and suggest other factors involved in determining the functional profile of CTL [25]. Cytokines such as IL-2 may also be important, as it was shown in mice that the addition of exogenous IL-2 resulted in higher TNF- $\alpha$ expression in CTL [26].

Here the functional profile of polyclonal human CTL populations specific for two different influenza A virus CTL epitopes was investigated in multiple HLA-A*0101/A*0201 positive subjects. In addition, the influence of IL-2 concentration during the in vitro expansion of these cells on the lytic activity and cytokine expression in these CTL was assessed.

\section{Materials and methods}

\section{Cells, virus, peptides and tetramers}

Four healthy blood donors, between 35 and 50 years of age, were selected according to genetic homology within the Alocus of human leucocyte antigen (HLA) class I molecules and their CTL response to epitopes $\mathrm{NP}_{44-52}$ and $\mathrm{M1}_{58-66}$ $[23,27]$. Genetic subtyping was performed using a commercial typing system (Genovision, Vienna, Austria). Peripheral blood mononuclear cells (PBMC) were isolated from whole blood by Lymphoprep ${ }^{\mathrm{TM}}$ (Nycomed, Oslo, Norway) density gradient centrifugation and cryopreserved at $-135^{\circ} \mathrm{C}$.

Sucrose gradient purified influenza A virus (H3N2) Resvir-9, a reassortant between influenza virus A/Nanchang/ 933/95 and A/Puerto Rico/8/34, was used for the infection of PBMC. The virus contains both the HLA-A ${ }^{\star} 0101$-restricted epitope $\mathrm{NP}_{44-52}$ (CTELKLSDY) and the HLA-A*0201restricted epitope $\mathrm{M1}_{58-66}$ (GILGFVFTL).

Synthetic peptides representing the epitope $\mathrm{NP}_{44-52}$ and the epitope $M 1_{58-66}$ were manufactured, high profile liquid chromatography (HPLC) purified and analysed by mass spectometry (Eurogentec, Seraing, Belgium). Peptides were dissolved in dimethyl sulphoxide (DMSO) $(5.0 \mathrm{mg} / \mathrm{ml})$, diluted in RPMI-1640 medium (Cambrex, East Rutherford, NJ, USA) to $100 \mu \mathrm{M}$ and stored at $-20^{\circ} \mathrm{C}$ until further use.

HLA-A $^{\star} 0101$ and HLA-A*0201 molecules were complexed with the $\mathrm{NP}_{44-52}$ and $\mathrm{M1}_{58-66}$ peptide, respectively, as described previously [28]. Both HLA-A peptide complexes were enzymatically biotinylated, fast protein liquid chromatography (FPLC) purified and tetramerized by addition of phycoerythrin (PE)-conjugated streptavidin (Sanquin Research at CLB, Amsterdam, the Netherlands). The $\mathrm{NP}_{44-52}$ peptide containing HLA-A ${ }^{\star} 0101$ tetramers are referred to as NP-Tm, while the $\mathrm{M}_{5--66}$ peptide containing HLA-A ${ }^{\star} 0201$ tetramers are referred to as M1-Tm.

\section{In vitro stimulation of $\mathrm{PBMC}$ with influenza $\mathrm{A}$ virus}

Stimulation of PBMC with influenza A virus was performed as described previously [27]. Cells were resuspended at $10^{6}$ cells/ml in RPMI-1640 medium supplemented with 10\% fetal calf serum (FCS) (Greiner Bio-one, Alphen a/d Rijn, the Netherlands), $2 \mathrm{mM}$ L-glutamine, $100 \mu \mathrm{g} / \mathrm{ml}$ streptomycin and $100 \mathrm{IU} / \mathrm{ml}$ penicillin (Cambrex, East Rutherford, NJ, USA) (R10F) and infected with Resvir-9 at a multiplicity of infection of 3 . After $1 \mathrm{~h}$ at $37^{\circ} \mathrm{C}$, the cells were washed once and resuspended in RPMI-1640 medium supplemented with $10 \%$ pooled human $\mathrm{AB}$ serum, $2 \mathrm{mM}$ L-glutamine, $100 \mu \mathrm{g} /$ $\mathrm{ml}$ streptomycin, $100 \mathrm{IU} / \mathrm{ml}$ penicillin and $20 \mu \mathrm{M} 2-\mathrm{ME}$ $(\mathrm{R} 10 \mathrm{H})$, and added to uninfected PBMC at a ratio of $1: 1$ in a $25-\mathrm{cm}^{2}$ culture flask. After 2 days, $2 \mathrm{U} / \mathrm{ml}$ (IL-2 $\mathrm{l}_{\mathrm{lo}}$ ) or $50 \mathrm{U} /$ $\mathrm{ml}$ (IL-2 ${ }_{\text {hi }}$ ) rhIL-2 (Chiron BV Amsterdam, the Netherlands) was added and the cells were incubated for another 6 days at $37^{\circ} \mathrm{C}$.

\section{CD107a mobilization assay}

Degranulation by CTL was assessed by mobilization of CD107 [29,30]. Two hundred thousand influenza A virus-stimulated PBMC were incubated in R10F containing Golgistop $^{\mathrm{TM}}$ (Monensin) (Becton Dickinson, Alphen a/d Rijn, the Netherlands), in the presence or absence of $10 \mu \mathrm{M}$ synthetic peptide for $5 \mathrm{~h}$ at $37^{\circ} \mathrm{C}$. During the $5 \mathrm{~h}$ incubation, fluorescein isothiocynate (FITC)-conjugated mouseantihuman CD107a monoclonal antibody (mAb) (clone H4A3, Becton Dickinson) was added to each well. Next the cells were washed once in phosphate buffered saline (PBS) containing Golgistop and 2\% FCS and incubated with NPTm or M1-Tm. After $20 \mathrm{~min}$ at $20^{\circ} \mathrm{C}$, peridinin chlorophyll protein (PerCP)-conjugated mouse-antihuman CD3 mAb (clone SK7, Becton Dickinson) and allophycocyanin (APC)conjugated mouse-antihuman CD8 mAb (clone DK25, Dako Cytomation, Glostrup, Denmark) were added for $10 \mathrm{~min}$ at $4^{\circ} \mathrm{C}$. Following one washing step, the cells were acquired and analysed using a FACSCalibur (Becton Dickinson) flow cytometer in combination with CellQuest Pro software (Becton Dickinson). The specific percentage CD107a ${ }^{+}$ 
cells of the NP- $\mathrm{Tm}^{+}$or $\mathrm{M} 1-\mathrm{Tm}^{+}$population was calculated using the following formula:

$\% \mathrm{CD} 107 \mathrm{a}^{+}$cells $_{(\text {peptide stimulated) }}-\% \mathrm{CD} 107 \mathrm{a}^{+}$cells $\mathrm{s}_{\text {(unstimulated) }}$.

\section{Intracellular cytokine staining}

IFN- $\gamma$ and TNF- $\alpha$ expression by influenza A virus-specific CTL was determined using intracellular cytokine staining as described previously [23,31]. Four hundred thousand PBMC were incubated in $200 \mu \mathrm{l} \mathrm{R} 10 \mathrm{~F}$ containing Golgistop $^{\mathrm{TM}}$ or Golgiplug ${ }^{\mathrm{TM}}$ for the IFN- $\gamma$ staining or TNF- $\alpha$ staining, respectively, according to recommendations of the manufacturer. Restimulation of $\mathrm{NP}_{44-52}$-specific and $\mathrm{M}_{58-66^{-}}$ specific effector cells was achieved by adding synthetic peptides to the wells at a concentration of $10 \mu \mathrm{M}$. Following $6 \mathrm{~h}$ incubation at $37^{\circ} \mathrm{C}$, the cells were washed once in PBS with $2 \%$ FCS and incubated with NP-Tm and M1-Tm complexes. After $20 \mathrm{~min}$ at $20^{\circ} \mathrm{C}$, FITC-conjugated mouse-antihuman CD8 mAb (clone DK25, Dako Cytomation) and PerCPconjugated mouse-antihuman $\mathrm{CD} 3 \mathrm{mAb}$ were added for $10 \mathrm{~min}$ at $4^{\circ} \mathrm{C}$. Following two washing steps, the cells were fixed (Cytofix ${ }^{\mathrm{TM}}$, Becton Dickinson), permeabilized (Cytoperm $^{\mathrm{TM}}$, Becton Dickinson) and incubated with APCconjugated mouse-antihuman IFN- $\gamma$ mAb (clone 4S.B3, Becton Dickinson) or APC-conjugated mouse-anti-human TNF- $\alpha$ mAb (clone 6401.1111, Becton Dickinson) for $30 \mathrm{~min}$ at $4^{\circ} \mathrm{C}$. Next the cells were washed once in PBS with $2 \%$ FCS and subsequently acquired and analysed using a FACSCalibur (Becton Dickinson) flow cytometer in combination with CellQuest Pro software (Becton Dickinson). At least 50000 events were acquired. The specific percentage IFN- $\gamma$ or TNF- $\alpha^{+}$cells of the NP-Tm ${ }^{+}$or $\mathrm{M} 1-\mathrm{Tm}^{+}$ population was calculated using the following formula: $\%$ IFN $-\gamma^{+}$or TNF- $\alpha^{+}$cells $s_{\text {(peptide stimulated) }}-\%$ IFN $-\gamma^{+}$or TNF- $\alpha^{+}$ cells (unstimulated). $_{\text {. }}$.

\section{Statistical analysis}

Mann-Whitney $U$-test was applied to determine statistical significance between $\mathrm{NP}-\mathrm{Tm}_{+}$or $\mathrm{M} 1-\mathrm{Tm}^{+}$cells of all four subjects or between IL- $2_{\mathrm{lo}}$ or IL- $2_{\mathrm{hi}}$ concentrations, using the average frequency of responding cells measured in two or three independently repeated assays. Significant differences within a single subject were determined by comparing the frequencies of both assays. A $P$-value below 0.05 was considered significant.

\section{Results}

\section{No effect of IL-2 on proportion of NP-Tm ${ }^{+}$and M1-Tm ${ }^{+}$cells}

CTL effector cell function was studied in two populations specific for two influenza A virus CTL epitopes following in vitro expansion of virus-specific T cells in the presence of 2 or $50 \mathrm{IU} / \mathrm{ml} \mathrm{IL-2.} \mathrm{The} \mathrm{frequency} \mathrm{of} \mathrm{NP}-\mathrm{Tm}^{+}$and $\mathrm{M} 1-\mathrm{Tm}^{+}$ cells ranged from $4 \cdot 5 \%$ to $15 \cdot 3 \%$ in the $\mathrm{CD}^{+}, \mathrm{CD}^{+} \mathrm{T}$ cell fraction. In subjects 1, 2 and 4 the frequency of NP- $\mathrm{Tm}^{+}$and $\mathrm{M} 1-\mathrm{Tm}^{+}$cells was similar, while in subject 3 the frequency of $\mathrm{M} 1-\mathrm{Tm}^{+}$cells was 1.5-fold higher than that the frequency of NP-Tm ${ }^{+}$cells (Fig. 1). The IL-2 concentration had no effect on the proportion of $\mathrm{Tm}^{+}$cells in the in vitro expanded virusspecific $\mathrm{T}$ cell populations (Fig. 1).

A 1.34-fold increase in cell number was observed following 8 days culture under high IL-2 (IL- $2_{\text {hi }}$ ) conditions. Culturing cells in low IL-2 (IL- $2_{\mathrm{lo}}$ ) concentrations resulted in a $1 \cdot 05$-fold increase in total cell number on day 8 (difference not statistically significant).

\section{CD107a mobilization on NP-Tm ${ }^{+}$and $\mathrm{M} 1-\mathrm{Tm}^{+}$cells}

The ability of NP-Tm ${ }^{+}$and M1- $\mathrm{Tm}^{+}$effector cells to degranulate upon antigenic stimulation was determined by measuring the percentage of $\mathrm{Tm}^{+}$cells expressing CD107a on their surface after antigenic restimulation. An example of such an analysis is shown in Fig. $2 \mathrm{a}-\mathrm{h}$. Unstimulated polyclonal effector cells specific for $\mathrm{NP}_{44-52}$ and the $\mathrm{M1}_{58-66}$ epitopes did not mobilize CD107a. However, after stimulation with the corresponding peptides, expression of CD107a was readily detected in NP-Tm and M1-Tm positive cells. The magnitude of CD107a expression was dependent on the IL-2 concentration added during the expansion of virus-specific CTL. This analysis was performed for all four study subjects (Fig. 2i).

Under IL-2 lo $_{0}$ conditions, the portion of NP-Tm ${ }^{+}$and $\mathrm{M} 1-$ $\mathrm{Tm}^{+}$cells expressing CD107a upon restimulation varied

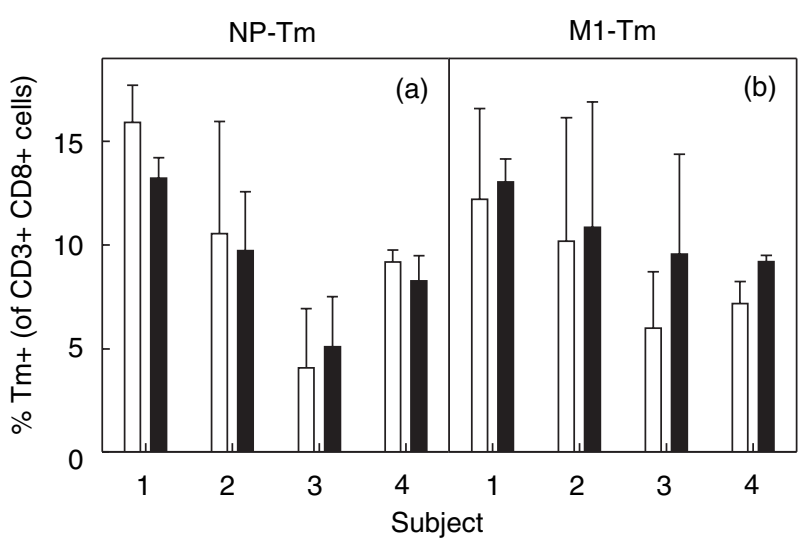

Fig. 1. Proportion of tetramer positive cells in influenza A virus stimulated peripheral blood mononuclear cells cultured under low or high interleukin (IL)-2 conditions. Peripheral blood mononuclear cells of four HLA-A ${ }^{\star} 0101$ and HLA-A ${ }^{\star} 0201+$ subjects were stimulated with influenza A virus for 8 days, in the presence of low (white bars) or high (black bars) IL-2 concentrations. The percentage NP- $\mathrm{Tm}^{+}$(a) and $\mathrm{M} 1-\mathrm{Tm}^{+}$(b) cells was determined in the $\mathrm{CD}^{+} \mathrm{CD}^{+}$cell fraction as described in the Materials and methods section. Presented are the average percentage $\mathrm{Tm}^{+}$cells, plus the standard deviation, of four independently repeated assays. 

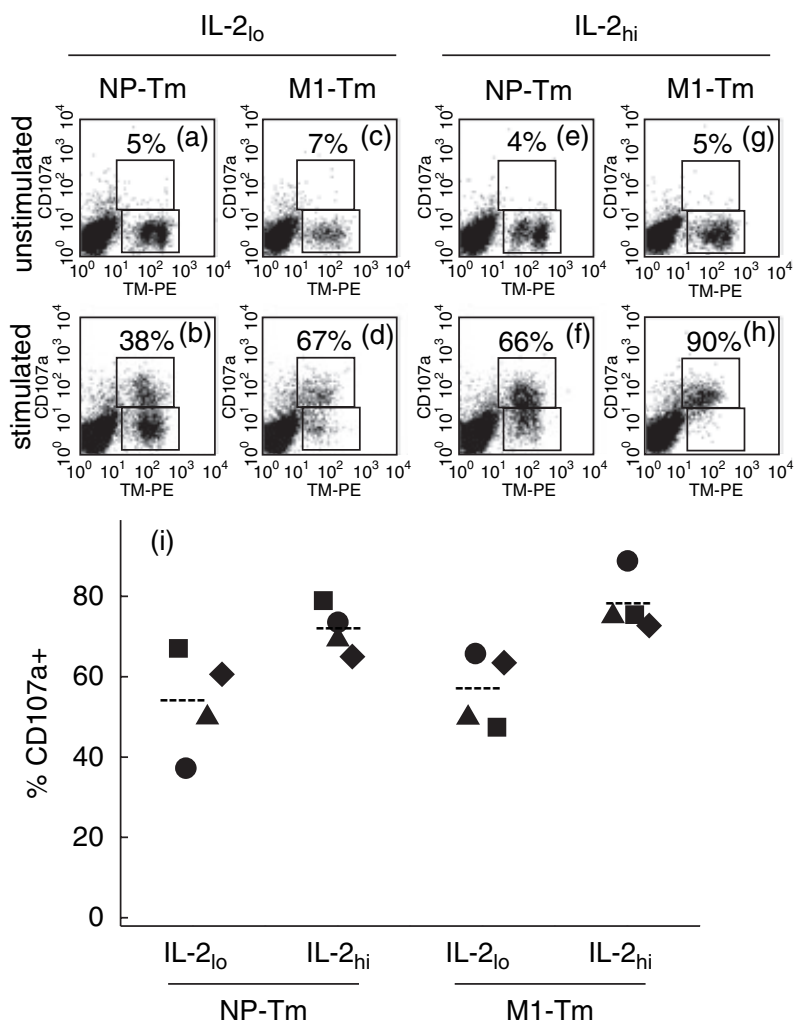

Fig. 2. CD107a staining on NP- and M1-Tm ${ }^{+}$cells cultured under low or high interleukin (IL)-2 conditions. Peripheral blood mononuclear cells of four HLA-A ${ }^{\star} 0101$ and HLA-A ${ }^{\star} 0201^{+}$subjects were stimulated with influenza $A$ virus for 8 days, in the presence of low (IL-2 $2_{\text {lo }}$ ) or high (IL- $2_{\mathrm{hi}}$ ) IL-2 concentrations. CD107a surface expression on NP-Tm ${ }^{+}$and $\mathrm{M} 1-\mathrm{Tm}^{+}$cells was determined after $5 \mathrm{~h}$ stimulation with cognate peptides. An example of CD107a surface expression is shown on NP-Tm ${ }^{+}$ cells $(\mathrm{a}, \mathrm{b}, \mathrm{e}, \mathrm{f})$ and $\mathrm{M} 1-\mathrm{Tm}^{+}$cells $(\mathrm{c}, \mathrm{d}, \mathrm{g}, \mathrm{h})$ cultured in IL- $2_{\mathrm{lo}}(\mathrm{a} \rightarrow \mathrm{d})$ and IL- $2_{\mathrm{hi}}(\mathrm{e} \rightarrow \mathrm{h})$ of subject 2 . In (i), the average percentage CD107a ${ }^{+}$ cells of the NP- $\mathrm{Tm}^{+}$and $\mathrm{M} 1-\mathrm{Tm}^{+}$cells are shown for all four subjects. Subject $1(\boldsymbol{\square})$ subject $2(\bullet)$, subject $3(\boldsymbol{\Delta})$, subject $4(\bullet)$. The indicated values in graphs $(\mathrm{a}-\mathrm{h})$ represent a single experiment, while graph (i) combines data of three independently repeated experiments.

between 33\% and 63\% in the four subjects (Fig. 2), demonstrating large subject-dependent differences. The average percentage $\mathrm{CD}_{107 \mathrm{a}^{+}}$cells was similar between $\mathrm{NP}-\mathrm{Tm}^{+}$ (54\%) and $\mathrm{M} 1-\mathrm{Tm}^{+}(56 \%)$ cells. In some individuals, however, the CD107a expression on the surface of NP- $\mathrm{Tm}^{+}$and $\mathrm{M} 1-\mathrm{Tm}^{+}$cells differed considerably. In subject 1 (squares; Fig. 2i) the CD107a expression on NP- $\mathrm{Tm}^{+}$cells (average of $67 \%)$ was significantly higher $(P=0.05)$ than the CD107a expression on $\mathrm{M} 1-\mathrm{Tm}^{+}$cells (average of $43 \%$ ), while in subject 2 (circles; Fig. 2i), the proportion of NP-Tm+ cells (average 37\%) expressing CD107a was lower than that of $\mathrm{M} 1-\mathrm{Tm}^{+}$ cells (average $61 \%)(P=0 \cdot 121)$. In the remaining two subjects, no difference $(<10 \%)$ in the portion of $\mathrm{CD} 107 \mathrm{a}^{+}$cells upon peptide restimulation was measured.

Next, we analysed if higher concentrations of IL-2 (IL- $\left.2_{\mathrm{hi}}\right)$, added during the 8-day culture period, had an effect on the capacity of $\mathrm{Tm}^{+}$cells to express CD107a on their surface upon peptide restimulation. In contrast to $\mathrm{Tm}^{+}$cells cultured under IL- $2_{\mathrm{lo}}$ conditions, CD107a expression on NP- $\mathrm{Tm}^{+}$and $\mathrm{M} 1-\mathrm{Tm}^{+}$cells of individual subjects did not differ significantly. However, the proportion of $\mathrm{Tm}^{+}$cells expressing CD107a following culture under IL- $2_{\text {hi }}$ conditions was significantly higher $(75 \%$ versus $55 \%$; $P<0.01)$ than following culture under IL- $2_{\text {lo }}$ conditions. The same was the case for NP- $\mathrm{Tm}^{+}$cells $(72 \%$ versus $54 \% ; P<0.05)$ and $\mathrm{M} 1-\mathrm{Tm}^{+}$cells (78\% versus $67 \% ; P<0 \cdot 05)$.

\section{IFN- $\gamma$ production by NP- $\mathrm{Tm}^{+}$and $\mathrm{M} 1-\mathrm{Tm}^{+}$cells}

The ability of $\mathrm{NP}-\mathrm{Tm}^{+}$and $\mathrm{M} 1-\mathrm{Tm}^{+}$cells from individual study subjects to produce IFN- $\gamma$ was determined. Eight-dayold effector cells, cultured under IL- $2_{\mathrm{lo}}$ or IL- $2_{\mathrm{hi}}$ conditions, were restimulated for $6 \mathrm{~h}$ with peptides to initiate IFN- $\gamma$ production. As shown in Fig. 3a-d for subject 2, IFN- $\gamma$ production was induced in a proportion of the NP- $\mathrm{Tm}^{+}$and M1$\mathrm{Tm}^{+}$cells after stimulation with peptide loaded stimulator cells.

In the four study subjects, IFN- $\gamma$ was produced in $55 \%$ (range 33-65\%) of the NP- $\mathrm{Tm}^{+}$cells cultured in low IL-2 $\left(\mathrm{IL}-2_{\mathrm{lo}}\right.$ ) concentrations (Fig. 3e). In M1- $\mathrm{Tm}^{+}$cells this percentage was $73 \%$ (range $66-80 \%$ ), which is significantly higher than the percentage IFN- $\gamma^{+}$cells in the NP- $\mathrm{Tm}^{+}$fraction $(P<0 \cdot 05$, Fig. 3$)$.

A larger proportion of NP- $\mathrm{Tm}^{+}$and $\mathrm{M} 1-\mathrm{Tm}^{+}$cells cultured under IL- $2_{\mathrm{hi}}$ conditions produced IFN- $\gamma$ upon restimulation. On average $73.5 \%$ of the NP- $\mathrm{Tm}^{+}$cells (range $56-82 \%$ ) produced IFN- $\gamma$, while in M1- $\mathrm{Tm}^{+}$cells the average percentage was $85 \%$ (range $79-90 \%$ ) (Fig. 3e). This difference in IFN- $\gamma$ expression by both $\mathrm{Tm}^{+}$cell populations was significantly different $(P<0.05$, Fig. 3$)$. The largest difference in proportion of IFN- $\gamma^{+}$cells between NP-Tm ${ }^{+}$(average 56\%) and M1$\mathrm{Tm}^{+}$(average 90\%) cells was found in subject 2 .

Finally, IFN- $\gamma$ production by $\mathrm{Tm}^{+}$cells cultured under IL- $2_{\text {hi }}$ and IL- $2_{\text {lo }}$ conditions was compared. Of the $\mathrm{Tm}^{+}$cells cultured under IL- $2_{\text {hi }}$ conditions $80 \%$ produced IFN- $\gamma$ upon peptide stimulation, while only $64 \%$ of the $\mathrm{Tm}^{+}$cells, cultured under IL- $2_{\text {lo }}$ conditions were IFN- $\gamma^{+}$. This difference in IFN- $\gamma$ production between both IL-2 conditions was statistically significant for $\mathrm{M} 1-\mathrm{Tm}^{+}$cells and all $\mathrm{Tm}^{+}$cells $(P<0 \cdot 05)$.

\section{TNF- $\alpha$ production by NP- $\mathrm{Tm}^{+}$and $\mathrm{M} 1-\mathrm{Tm}^{+}$cells}

In addition to IFN- $\gamma$, the production of a second proinflammatory cytokine, TNF- $\alpha$, was investigated. The TNF- $\alpha$ expression by $\mathrm{NP}-\mathrm{Tm}^{+}$and $\mathrm{M} 1-\mathrm{Tm}^{+}$cells of subject 2 is shown in Fig. 4a-d. After expansion under IL- $2_{10}$ conditions $26 \%$ of the NP- $\mathrm{Tm}^{+}$cells and $46 \%$ of the $\mathrm{M} 1-\mathrm{Tm}^{+}$cells produced TNF- $\alpha$ upon restimulation (Fig. 4e). After expansion under IL- $2_{\text {hi }}$ conditions, these numbers increased. On 

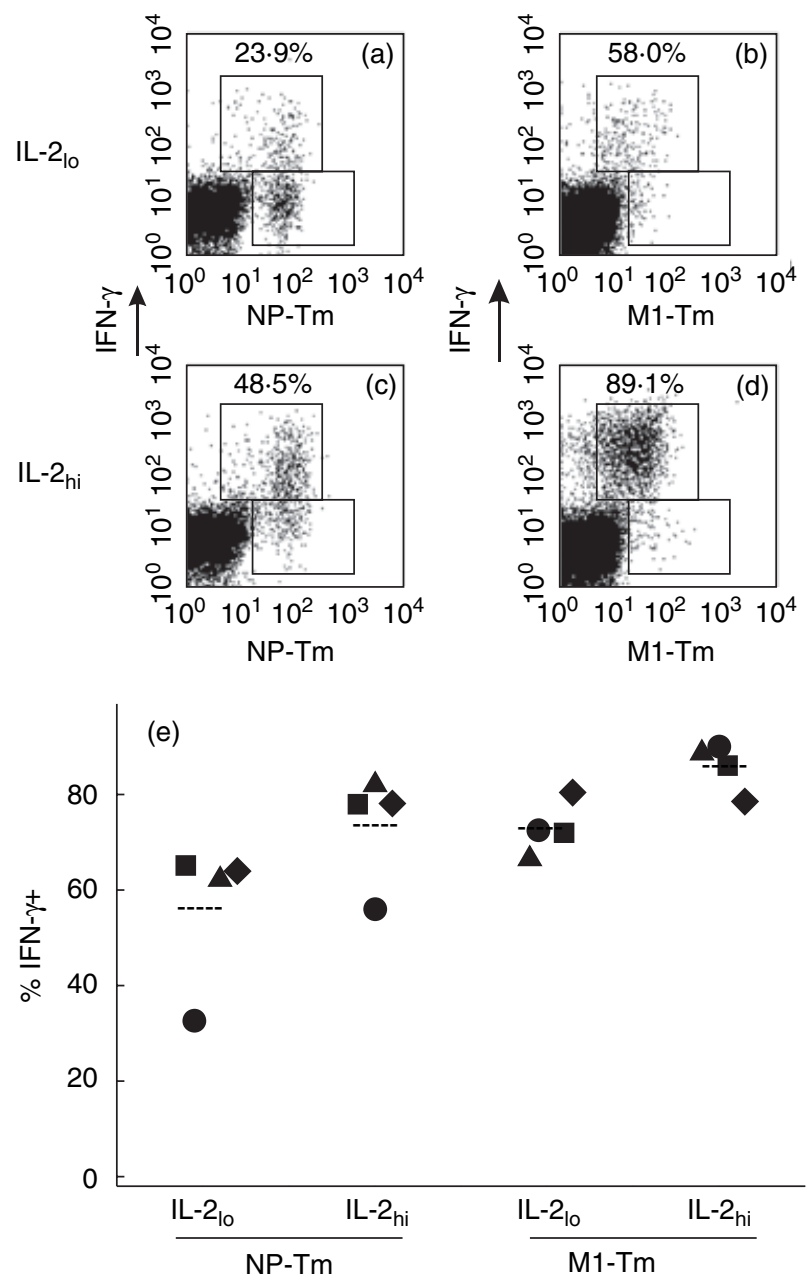

Fig. 3. Intracellular interferon (IFN)- $\gamma$ staining of NP-Tm ${ }^{+}$and M1$\mathrm{Tm}^{+}$cells cultured under low or high interleukin (IL)- 2 conditions. Peripheral blood mononuclear cells of four HLA-A ${ }^{\star} 0101$ and HLA$\mathrm{A}^{\star} 0201^{+}$subjects were stimulated with influenza A virus for 8 days, in the presence of low (IL-2 $2_{\mathrm{lo}}$ ) or high (IL-2 $\mathrm{h}_{\mathrm{hi}}$ ) IL-2 concentrations. Intracellular IFN- $\gamma$ staining was performed as described in Materials and methods following peptide restimulation of NP-Tm+ and M1- $\mathrm{Tm}^{+}$cells. IFN- $\gamma$ staining in NP-Tm ${ }^{+}$cells (a and c) and $\mathrm{M} 1-\mathrm{Tm}^{+}$cells (b and d) cultured in IL-2 $2_{\text {lo }}\left(\mathrm{a}\right.$ and b) and IL- $2_{\text {hi }}(\mathrm{c}$ and d) of subject 2 are shown as an example. In (e), the percentage IFN- $\gamma^{+}$cells of the NP-Tm ${ }^{+}$and $\mathrm{M} 1-\mathrm{Tm}^{+}$cells are presented for all four subjects. Subject 1 (ם) subject $2(\bullet)$, subject $3(\boldsymbol{\Delta})$, subject $4(\bullet)$. The indicated values in graphs (a-d) represent a single experiment, while graph (e) combines data of two independently repeated experiments.

average $48 \%$ of the NP-Tm ${ }^{+}$cells produced TNF- $\alpha$, which was significantly $(P<0.05)$ lower than the average percentage of TNF- $\alpha^{+} \mathrm{M} 1-\mathrm{Tm}^{+}$cells (67\%) (Fig. 4).

Overall, the proportion of $\mathrm{Tm}^{+}$cells producing TNF- $\alpha$ was higher after expansion under IL- $2_{\text {hi }}$ conditions than after expansion under IL-2 $2_{\text {lo }}$ conditions (Fig. 4e). These differences were statistically significant for $\mathrm{M} 1-\mathrm{Tm}^{+}$and all $\mathrm{Tm}^{+}$ cells $(P<0 \cdot 05)$ but not for NP-Tm ${ }^{+}$cells $(P=0 \cdot 083)$.

\section{Discussion}

The functional properties of polyclonal CTL populations specific for two influenza A virus epitopes were studied in four HLA-A $^{\star} 0101$, HLA- $A^{\star} 0201$ positive study subjects using a combination of tetramer-staining and cell-surface CD107a or intracellular cytokine staining. Epitopedependent as well as subject-dependent differences in the expression of these effector cell molecules were identified.

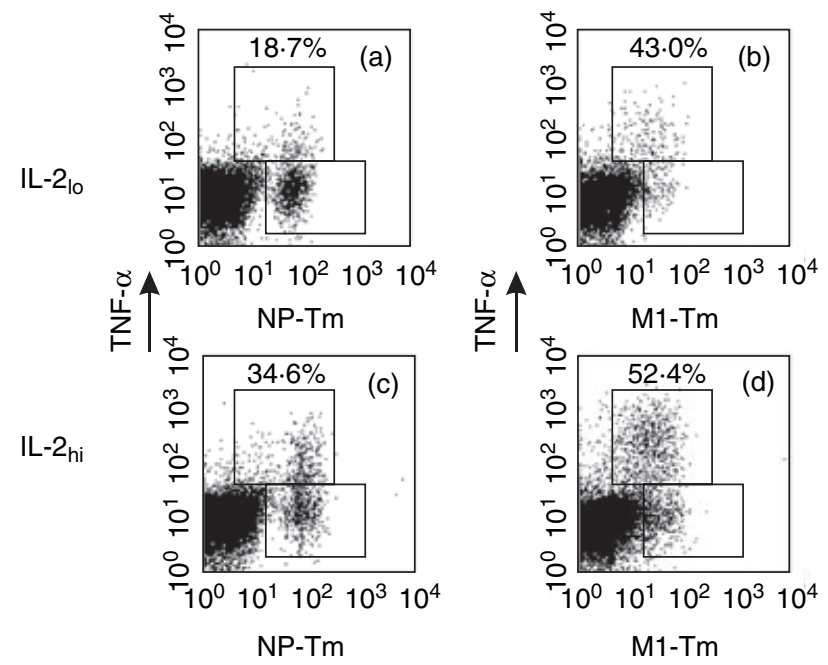

(e)

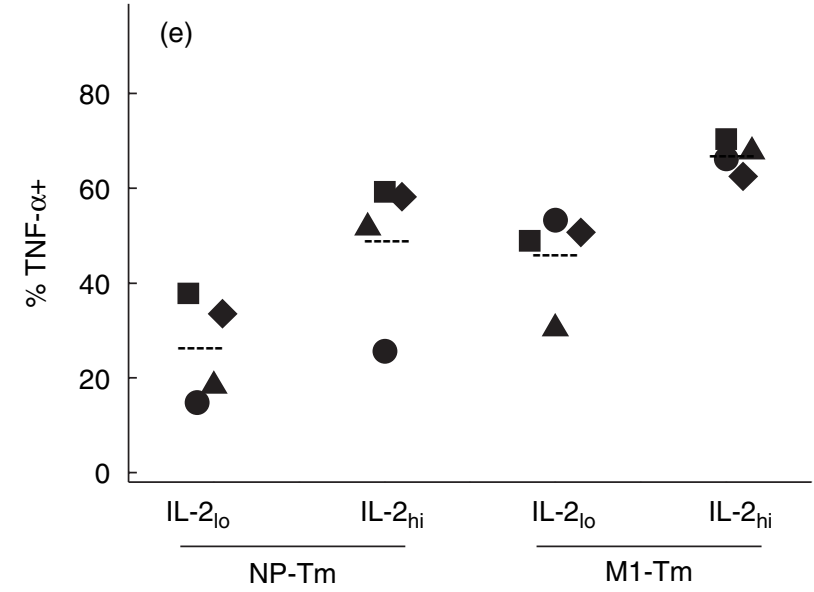

Fig. 4. Intracellular tumour necrosis factor (TNF)- $\alpha$ staining of NP$\mathrm{Tm}^{+}$and M1-Tm ${ }^{+}$cells cultured under low or high interleukin (IL)-2 conditions. Peripheral blood mononuclear cells of four HLA-A ${ }^{\star} 0101$ and HLA-A ${ }^{\star} 0201^{+}$subjects were stimulated with influenza A virus for 8 days, in the presence of low (IL-2 $2_{\mathrm{lo}}$ ) or high (IL- $\left.2_{\text {hi }}\right)$ IL-2 concentrations. Intracellular TNF- $\alpha$ staining was performed as described in Materials and methods, following peptide restimulation of NP- $\mathrm{Tm}^{+}$and $\mathrm{M} 1-\mathrm{Tm}^{+}$ cells. TNF- $\alpha$ staining in NP-Tm ${ }^{+}$cells (a and c) and M1-Tm ${ }^{+}$cells ( $b$ and d) cultured in IL- $2_{\text {lo }}$ (a and b) and IL- $2_{\text {hi }}(\mathrm{c}$ and d) of subject 2 are shown as an example. In (e), the percentages TNF- $\alpha^{+}$cells of the NP- $\mathrm{Tm}^{+}$and $\mathrm{M} 1-\mathrm{Tm}^{+}$cells are presented for all four subjects. Subject 1 (ם) subject 2 $(\bullet)$, subject $3(\boldsymbol{\Delta})$, subject $4(\bullet)$. The indicated values in graphs (a-d) represent a single experiment, while graph (e) combines data of two independently repeated experiments. 

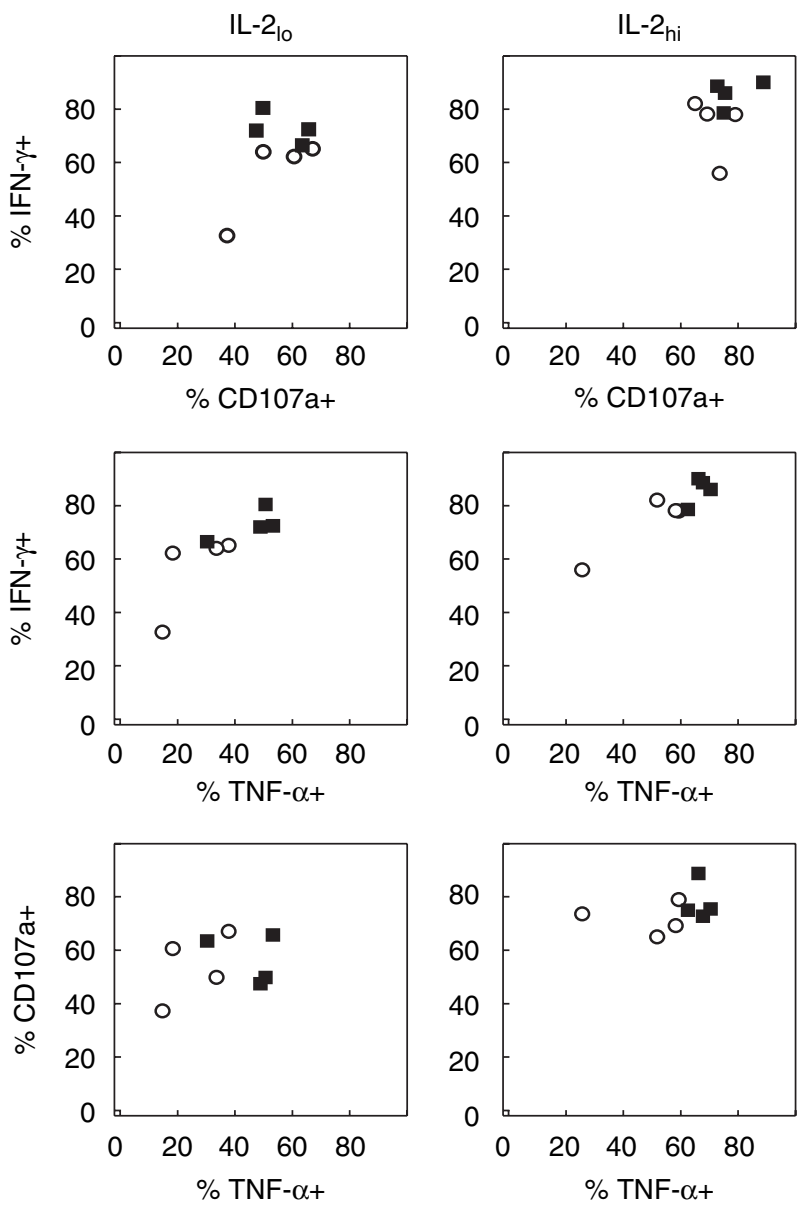

Fig. 5. Functional comparison of NP- $\mathrm{Tm}^{+}$and $\mathrm{M} 1-\mathrm{Tm}^{+}$cells cultured under interleukin (IL)- $2_{\mathrm{lo}}$ and IL- $2_{\mathrm{hi}}$ conditions. The proportion of $\mathrm{NP}-\mathrm{Tm}^{+}$(white circles) and M1- $\mathrm{Tm}^{+}$cells (black squares) mobilizing CD107a or expressing interferon (IFN) $-\gamma$ or tumour necrosis factor (TNF)- $\alpha$ were plotted against each other for both IL-2 $2_{\text {lo }}(a, c, e)$ and IL- $2_{\text {hi }}$ conditions (b, d, f). The data were obtained from Figs $2-4$.

Also, IL-2 concentration influenced the functional profile of these polyclonal CTL populations.

Mobilization of CD107a (LAMP-1) and CD107b (LAMP-

2 ) to the cell surface of CTL has been identified recently as a marker of degranulation of perforin and granzyme [29], and therefore as a surrogate marker of target cell lysis. Thus, in combination with tetramer-staining, CD107a staining allows the investigation of the cytolytic capacity of polyclonal CTL populations specific for single epitopes. In addition to subject-dependent differences in the lytic capacity of CTL, epitope-dependent differences were also identified in two of four subjects studied. These differences were profound in cells cultured in IL-2 $2_{\text {lo }}$ conditions. A fraction of the polyclonal $\mathrm{Tm}^{+}$population did not express CD107a upon stimulation, a phenomenon reported previously by others [32]. It is unlikely, however, that these CD107a negative cells form a subset of the polyclonal $\mathrm{Tm}^{+}$population, with a different TCR and CDR3 profile [32].
For cytokine expression profiles of the $\mathrm{Tm}^{+}$cells populations, subject- and epitope-dependent differences were also observed (Fig. 5). In particular, NP- $\mathrm{Tm}^{+}$cells of subject 2 were consistently less functional than the M1-Tm+ cells of the same subject or NP- $\mathrm{Tm}^{+}$cells of other subjects. TCR avidity analysis of NP- $\mathrm{Tm}^{+}$cells of these four subjects demonstrated that the avidity of NP- $\mathrm{Tm}^{+}$cells of subject 2 is significantly lower than the TCR avidity of the NP- $\mathrm{Tm}^{+}$cells of the other three subjects (data not shown). Although a correlation between TCR avidity and the functional profile of epitope-specific CTL has been described previously [25], it is of interest that epitope-specific $\mathrm{T}$ cell repertoires in subjects differ regarding their functional avidity. The underlying mechanism for these differences remains to be elucidated.

Comparison of average frequencies of CD107a, IFN- $\gamma$ and TNF- $\alpha$ positive cells within the $\mathrm{Tm}^{+}$cell population (Fig. 5) showed that the proportion of epitope-specific CTL mobilizing CD107a and producing IFN- $\gamma$ is similar and larger than the proportion of epitope-specific $\mathrm{T}$ cells producing TNF- $\alpha$. These data indicate that the hierarchy in effector CTL function is CD107a $=$ IFN- $\gamma>$ TNF- $\alpha$, confirming and extending the previously reported cytokine production hierarchy of influenza virus-specific CTL [33].

In a previous study it was demonstrated that HLA- $A^{\star} 0101$ restricted influenza A virus-specific CTL were more prone to produce TNF- $\alpha$ than IFN- $\gamma$, while influenza A virus-specific CTL restricted by HLA- $A^{\star} 0201$ and $-B^{\star} 3501$ produced more IFN- $\gamma$ than TNF- $\alpha$ [23]. In the present study, this was not the case for the HLA- $\mathrm{A}^{\star} 0101$ restricted NP- $\mathrm{Tm}^{+}$cells that produced mainly IFN- $\gamma$. CTL responses to other HLA-A1 restricted epitopes may have been responsible for the predominant TNF- $\alpha$ expression observed previously.

We also noted a significant effect of IL- 2 on the functionality of polyclonal epitope-specific CTL. High IL-2 concentrations during effector cell differentiation resulted in highly efficient CTL, while effector cell differentiation in IL- $2_{10}$ conditions resulted in CTL less efficient in mobilizing CD107a and producing IFN- $\gamma$ and TNF- $\alpha$. The effect of IL- 2 on effector cell function of CTL has been reported previously for T cells from humans, monkeys and mice [26,34-38]. In humans, only CTL clones or T cell lines, passaged multiple times in vitro, have been studied. Increased IFN- $\gamma$ production and lysis by human dengue virus-specific CTL clones cultured under IL- $2_{\mathrm{hi}}$ conditions were observed [37]. Also, it has been found more recently that IL-2 had a positive effect on influenza A virus epitope $\left(\mathrm{M}_{58-66}\right)$-specific CTL that had been stimulated three times with peptide-pulsed APC before their functional properties were investigated [36]. Finally, addition of exogenous IL-2 following RSV challenge of mice resulted in increased effector cell function of RSV-specific CTL [26]. The mechanism of the stimulatory effect of IL-2 on effector cell function is as yet unknown. Recent literature suggests a role for regulatory T-cells which may inhibit the effector cell function of CTL, that is inhibited in turn by IL$2[39,40]$. Increased effector cell function as a result of IL-2 
was also found for influenza virus stimulated natural killer (NK)-cells [41], the vital role of which was demonstrated previously in mice in the induction of an influenza virusspecific CTL response [42]. Our data also have important implications for the development of future vaccines, aiming at the induction of CTL-mediated immunity. These vaccines should also induce strong IL-2-producing $\mathrm{T}$ helper cell responses, which facilitate the induction of functional antigen-specific CTL.

Collectively, the data presented here demonstrate that there is functional heterogeneity among influenza virusspecific $\mathrm{CD}^{+} \mathrm{T}$ cells. Functional properties of CTL depend on the epitope that is recognized, but also $\mathrm{Tm}^{+}$cell populations displayed functional differences depending on the subject from which they were obtained. In addition, the concentration of IL-2 used during expansion or virus-specific T lymphocytes has a major influence on the functionality of these cells. These variables should be taken into account when interpreting CTL responses induced after infection of vaccination.

\section{Acknowledgements}

We acknowledge K. Sintnicolaas, W. Levering and S. Sakko for organizing blood collection of HLA-typed blood donors (Bloodbank Rotterdam, Netherlands). This work was supported by EU grant QLRT-2001-01034 (Novaflu).

\section{References}

1 Bender BS, Croghan T, Zhang L et al. Transgenic mice lacking class I major histocompatibility complex-restricted $\mathrm{T}$ cells have delayed viral clearance and increased mortality after influenza virus challenge. J Exp Med 1992; 175:1143-5.

2 McMichael AJ, Gotch FM, Noble GR et al. Cytotoxic T-cell immunity to influenza. N Engl J Med 1983; 309:13-7.

3 Barry M, Bleackley RC. Cytotoxic T lymphocytes: all roads lead to death. Nat Rev Immunol 2002; 2:401-9.

4 Geginat J, Lanzavecchia A, Sallusto F. Proliferation and differentiation potential of human $\mathrm{CD}^{+}$memory T-cell subsets in response to antigen or homeostatic cytokines. Blood 2003; 101:4260-6.

5 Hamann D, Baars PA, Rep MH et al. Phenotypic and functional separation of memory and effector human $\mathrm{CD}^{+} \mathrm{T}$ cells. J Exp Med 1997; 186:1407-18.

6 Rufer N, Zippelius A, Batard P et al. Ex vivo characterization of human $\mathrm{CD}^{+} \mathrm{T}$ subsets with distinct replicative history and partial effector functions. Blood 2003; 102:1779-87.

7 Tussey L, Speller S, Gallimore A et al. Functionally distinct CD8 ${ }^{+}$ memory $\mathrm{T}$ cell subsets in persistent EBV infection are differentiated by migratory receptor expression. Eur J Immunol 2000; 30:1823-9.

8 Sallusto F, Langenkamp A, Geginat J et al. Functional subsets of memory T cells identified by CCR7 expression. Curr Top Microbiol Immunol 2000; 251:167-71.

9 Sallusto F, Mackay CR, Lanzavecchia A. The role of chemokine receptors in primary, effector, and memory immune responses. Annu Rev Immunol 2000; 18:593-620.
10 Sallusto F, Lenig D, Forster R et al. Two subsets of memory T lymphocytes with distinct homing potentials and effector functions. Nature 1999; 401:708-12.

11 Aandahl EM, Sandberg JK, Beckerman KP et al. CD7 is a differentiation marker that identifies multiple CD8 T cell effector subsets. J Immunol 2003; 170:2349-55.

12 van Lier RA, ten Berge IJ, Gamadia LE. Human CD8(+) T-cell differentiation in response to viruses. Nat Rev Immunol 2003; 3:931-9.

13 Appay V, Nixon DF, Donahoe SM et al. HIV-specific CD8(+) T cells produce antiviral cytokines but are impaired in cytolytic function. J Exp Med 2000; 192:63-75.

14 Appay V, Dunbar PR, Callan M et al. Memory CD8 ${ }^{+} \mathrm{T}$ cells vary in differentiation phenotype in different persistent virus infections. Nat Med 2002; 8:379-85.

15 Sandberg JK, Fast NM, Nixon DF. Functional heterogeneity of cytokines and cytolytic effector molecules in human $\mathrm{CD} 8^{+} \mathrm{T}$ lymphocytes. J Immunol 2001; 167:181-7.

16 Tussey LG, Nair US, Bachinsky M et al. Antigen burden is major determinant of human immunodeficiency virus-specific $\mathrm{CD} 8^{+} \mathrm{T}$ cell maturation state: potential implications for therapeutic immunization. J Infect Dis 2003; 187:364-74.

17 He XS, Mahmood K, Maecker HT et al. Analysis of the frequencies and of the memory $\mathrm{T}$ cell phenotypes of human $\mathrm{CD}^{+} \mathrm{T}$ cells specific for influenza A viruses. J Infect Dis 2003; 187:1075-84.

18 Chang J, Braciale TJ. Respiratory syncytial virus infection suppresses lung $\mathrm{CD}^{+}$T-cell effector activity and peripheral $\mathrm{CD} 8^{+}$ T-cell memory in the respiratory tract. Nat Med 2002; 8:5460.

19 Ravkov EV, Myrick CM, Altman JD. Immediate early effector functions of virus-specific $\mathrm{CD} 8^{+} \mathrm{CCR} 7^{+}$memory cells in humans defined by HLA and CC chemokine ligand 19 tetramers. J Immunol 2003; 170:2461-8.

20 Belz GT, Xie W, Doherty PC. Diversity of epitope and cytokine profiles for primary and secondary influenza a virus-specific $\mathrm{CD} 8^{+}$ T cell responses. J Immunol 2001; 166:4627-33.

21 Catalina MD, Sullivan JL, Brody RM et al. Phenotypic and functional heterogeneity of EBV epitope-specific $\mathrm{CD}^{+} \mathrm{T}$ cells. J Immunol 2002; 168:4184-91.

22 Hislop AD, Gudgeon NH, Callan MF et al. EBV-specific CD8 ${ }^{+} \mathrm{T}$ cell memory: relationships between epitope specificity, cell phenotype, and immediate effector function. J Immunol 2001; 167:201929.

23 Boon AC, de Mutsert G, Graus YM et al. Preferred HLA usage and HLA dependent differential cytokine expression in the influenza virus-specific cytotoxic T lymphocyte response. J Immunol 2004; 172:4435-43.

24 Hofmann M, Radsak M, Rechtsteiner G et al. T cell avidity determines the level of CTL activation. Eur J Immunol 2004; 34:1798806.

25 Kristensen NN, Madsen AN, Thomsen AR et al. Cytokine production by virus-specific $\mathrm{CD} 8(+) \mathrm{T}$ cells varies with activation state and localization, but not with TCR avidity. J General Virol 2004; 85:1703-12.

26 Chang J, Choi SY, Jin HT et al. Improved effector activity and memory CD8 $\mathrm{T}$ cell development by IL-2 expression during experimental respiratory syncytial virus infection. J Immunol 2004; 172:503-8.

27 Boon AC, de Mutsert G, Graus YM et al. The magnitude and specificity of influenza A virus-specific cytotoxic T-lymphocyte 
responses in humans is related to HLA-A and -B phenotype. J Virol 2002; 76:582-90.

28 Altman JD, Moss PA, Goulder PJ et al. Phenotypic analysis of antigen-specific T lymphocytes. Science 1996; 274:94-6.

29 Betts MR, Brenchley JM. Price DA et al. Sensitive and viable identification of antigen-specific $\mathrm{CD} 8^{+} \mathrm{T}$ cells by a flow cytometric assay for degranulation. J Immunol Meth 2003; 281:65-78.

30 Rubio V, Stuge TB, Singh N et al. Ex vivo identification, isolation and analysis of tumor-cytolytic T cells. Nat Med 2003; 9:1377-82.

31 Boon AC, Fringuelli E, Graus YM et al. Influenza A virus specific T cell immunity in humans during aging. Virology 2002; 299:100-8.

32 Betts MR. Price DA, Brenchley JM et al. The functional profile of primary human antiviral $\mathrm{CD} 8^{+} \mathrm{T}$ cell effector activity is dictated by cognate peptide concentration. J Immunol 2004; 172:6407-17.

33 La Gruta NL, Turner SJ, Doherty PC. Hierarchies in cytokine expression profiles for acute and resolving influenza virus-specific $\mathrm{CD}^{+} \mathrm{T}$ cell responses: correlation of cytokine profile and TCR avidity. J Immunol 2004; 172:5553-60.

34 Xiong Y, Luscher MA, Altman JD et al. Simian immunodeficiency virus (SIV) infection of a rhesus macaque induces SIV-specific CD8(+) T cells with a defect in effector function that is reversible on extended interleukin-2 incubation. J Virol 2001; 75:3028-33.
35 Manjunath N, Shankar P, Wan J et al. Effector differentiation is not prerequisite for generation of memory cytotoxic $\mathrm{T}$ lymphocytes. J Clin Invest 2001; 108:871-8.

36 Lyngstrand ST, Wurtzen PA, Odum N et al. IL-15 induces unspecific effector functions in human peptide-specific $\mathrm{CD}^{+} \mathrm{T}$-cell cultures. Scand J Immunol 2002; 56:602-10.

37 Livingston PG, Toomey S, Kurane I et al. Modulation of the functions of dengue virus-specific human $\mathrm{CD}^{+}$cytotoxic $\mathrm{T}$ cell clone by IL-2, IL-7 and IFN gamma. Immunol Invest 1995; 24:619-29.

38 Cousens LP, Orange JS, Biron CA. Endogenous IL-2 contributes to $\mathrm{T}$ cell expansion and IFN-gamma production during lymphocytic choriomeningitis virus infection. J Immunol 1995; 155:5690-9.

39 Nelson BH. IL-2, regulatory T cells, and tolerance. J Immunol 2004; 172:3983-8.

40 Bach JF. Regulatory T cells under scrutiny. Nat Rev Immunol 2003; 3:189-98.

41 He XS, Draghi M, Mahmood K et al. T cell-dependent production of IFN-gamma by NK cells in response to influenza A virus. J Clin Invest 2004; 114:1812-9.

42 Kos FJ, Engleman EG. Role of natural killer cells in the generation of influenza virus-specific cytotoxic T cells. Cell Immunol 1996; 173:1-6. 